\title{
A NEW THAUMASTOCYONINAE (AMPHICYONIDAE, CARNIVORA) FROM THE EARLY MIOCENE OF TUCHOŘICE, THE CZECH REPUBLIC
}

\author{
JORGE MORALES ${ }^{1, *}$, OLDŘICH FEJFAR ${ }^{2}$, ELMAR HEIZMANN³ ${ }^{3}$ JAN WAGNER ${ }^{2}$, ALBERTO VALENCIANO $^{4,5}$, \\ JUAN ABELLA ${ }^{6,7}$
}

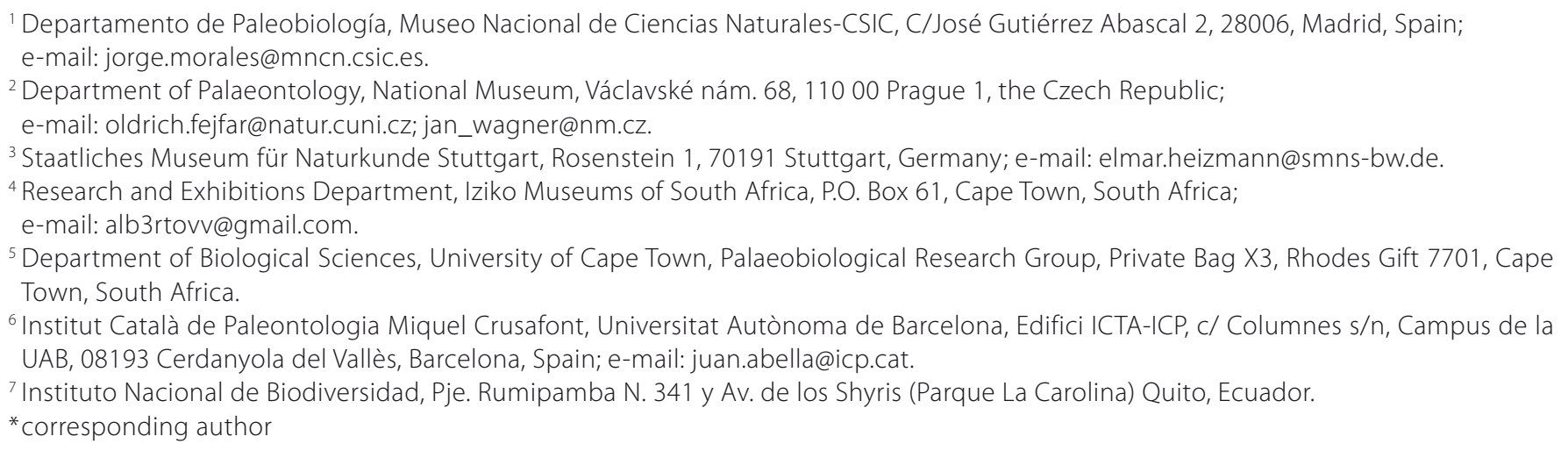

Morales, J., Fejfar, O., Heizmann, E., Wagner, J., Valenciano, A., Abella, J. (2019): A new Thaumastocyoninae (Amphicyonidae, Carnivora) from the early Miocene of Tuchořice, the Czech Republic. - Fossil Imprint, 75(3-4): 397-411, Praha. ISSN 25334050 (print), ISSN 2533-4069 (on-line).

\begin{abstract}
New Amphicyonidae fossil remains from the early Miocene site of Tuchořice (the Czech Republic) confirm the presence of a new Thaumastocyoninae taxon: Peignecyon felinoides $\mathrm{n}$. gen. et $\mathrm{n}$. $\mathrm{sp}$. It is characterized by a peculiar combination of plesiomorphic and derived morphological traits. The new genus can be defined by a long and sharp mandible diastema, loss of mesial premolars (p2-p3), p4 with an inclined distally high main cuspid, moderate sectorial carnassial teeth, m1 with relict metaconid, and talonid and trigonid of similar width, and reduced M2 and $\mathrm{m} 2$. In the phylogenetic analysis the Thaumastocyoninae form a monophyletic group characterized by the start of the m2/M2 reduction, still moderate in Crassidia intermedia (VON Meyer, 1849), but remarkable in the other species of the clade. Peignecyon felinoides already shows the advanced features defining the Thaumastocyoninae, and constitutes the sister group of the most specialized genera Tomocyon Viret, 1929b and Thaumastocyon Sthelin et Helbing, 1925. Consequently, it can be considered an excellent link between this group and the more primitive members of the tribe Ysengrini (Ysengrinia Ginsburg, 1966 and Crassidia HeizmannN et Kordikova, 2000). Peignecyon felinoides shows that the trend towards hypercarnivory had already emerged in the European early Miocene fauna, thus helping to understand the complex evolution of the Amphicyonidae during the Miocene.
\end{abstract}

Key words: Thaumastocyoninae, Amphicyonidae, systematics, Miocene, Europe

Received: April 8, 2019| Accepted: June 21, 2019| Issued: December 30, 2019

\section{Introduction}

The Amphicyonidae family represented one of the most characteristic groups of carnivorans in the European faunas for approximately 35 million years, from its first appearance during the Eocene (ca. $40 \mathrm{Ma}$ ) to its extinction in the late Miocene (ca. $5 \mathrm{Ma}$ ). Despite the success of the group and the large temporal range registered, they generally maintained a very homogeneous dental pattern, characterized by the large size (similar to that of the largest extant terrestrial carnivores), robustness of the crushing molars (M1-M2, and $\mathrm{m} 2-\mathrm{m} 3, \mathrm{~m} 1$-talonid), and the sharp and robust carnassial teeth ( $\mathrm{m} 1$ and $\mathrm{P} 4)$. However, despite the constancy of this dental pattern, certain divergent adaptations took place. Some involved an increase in the molar dental surface, tending towards a less specialized diet, others exhibited a reduction of this grinding surface, while mesio-distally stretching the carnassials, by way of an adaption to a more carnivorous diet. This hypercarnivory has been seen to recur throughout the amphicyonid fossil record (Hunt 1998), first during the Oligocene and early Miocene in the North American Daphoenidae Hough, 1948 and its 
Eurasian relatives, the Haplocyoninae DE BonIS, 1966, and subsequently, with the Thaumastocyoninae HüRZELER, 1940, which appear at the same time as the last haplocyonines (Hunt 1998, Peigné and Heizmann 2003, Wang et al. 2016). The phylogenetic relationships within the Amphicyonidae species present notorious difficulties, as can be seen in some previous studies (Viranta 1996, Peigné et al. 2008, Morales et al. 2016). Several problems in this regard involve the proliferation of species, some of them defined with few diagnostic characters, the coexistence of different species in the same locality, the broad interspecific variability, and the perception of a parallel evolution to the amphicyonid lineages, with the multiplication of homoplasic characters. The present paper attempts to describe the hypercarnivorous Amphicyonidae from Tuchořice, placing particular emphasis upon the systematic revision of the Thaumastocyoninae subfamily.

\section{Tuchořice fossil locality}

The fossiliferous locality of Tuchorice is located in North Bohemia, the Czech Republic, close to the southwest margin of the Most brown coal basin, near the villages of Tuchořice and Lipno (Fejfar and Heizmann 2016). The freshwater limestones of Tuchořice were believed to be the early Miocene equivalent of the underlying marls of the main brown coal seam located in the North Bohemian Tertiary basin. The mammal remains from Tuchořice have been known since the nineteenth century. The first study of mammalian fossils from there was of fragmentary rhinoceros teeth reported by Suess (1861). Much richer finds from the travertines near Tuchořice were collected many years later by $\mathrm{O}$. Fejfar. The small mammalian fauna has extremely low diversity in comparison with the nearby locality of Merkur-North (= Ahníkov 1) (Fejfar et al. 2003). Remains of large mammals are well preserved and diversified, especially the Rhinocerotidae (Heissig and Fejfar 2007) and carnivores (Fejfar and Heizmann 2016). The abundance of carnivore predators is interpreted as due to the supposed "trapping affect" of the $\mathrm{CO}_{2}$-rich exhalations of the hot mineral springs. The abundance of Amphicyonidae teeth is remarkable, and there is evidence of at least five species, ranging from the small Amphicyon schlosseri DeHM, 1950 to the biggest Megamphicyon giganteus (SchINZ, 1825). The Amphicyonidae association is comparable to that of Wintershof-West (Dehm 1950), but with some differences; in Tuchorrice, Pseudocyon bohemicus Schlosser, 1901 is abundant, while this species is absent in Wintershof-West. Amphicyon dietrichi DeHM, 1950 is taxonomically close, but scarce. The most striking difference is the presence in Tuchořice of a new Thaumastocyoninae species, a group that seems to be absent in Wintershof-West. The Tuchorrice sample is the most complete fossil record of this elusive group. New collections and comparisons of similar mammalian taxa have shown the more advanced character of some species, indicating a somewhat higher level in the Miocene mammalian zone MN 3 (Fejfar et al. 2003, Heissig and Fejfar 2007, Fejfar and Heizmann 2016). The Tuchořice fossil localities are now by law Protected Palaeontological Site.

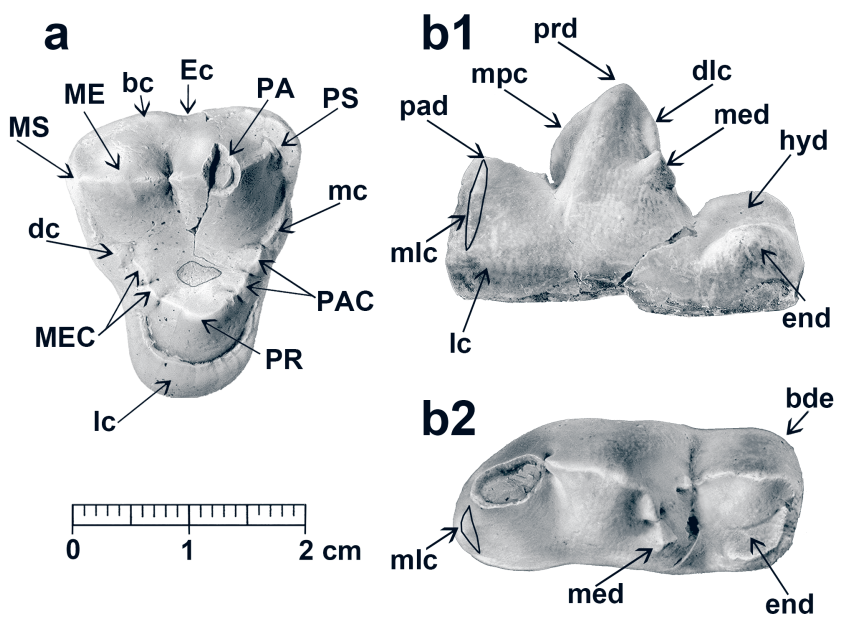

Text-fig. 1. Dental nomenclature. Peignecyon felinoides n. gen. et n. sp. a) TU 73916 upper right M1 in occlusal view; b) TU 7391147 lower right $\mathrm{m} 1, \mathrm{~b} 1)$ lingual view, b2) occlusal view. Abbreviations: bde, basal distobuccal expansion*; bc, buccal cingulum; Ec, ectoflexus; dc, distal cingulum; dlc, distolingual cristid; end, entoconid; hyd, hypoconid; lc, lingual cingulum; ME, metacone; MEC, metaconule; mc, mesial cingulum; med, metaconid; mlc, mesiolingual cristid; mpc, mesial protoconid cristid; MS, metastyle; PA, paracone; PAC, paraconule; pad, paraconid; PR, protocone; prd, protoconid; PS, parastyle. *Not developed in Peignecyon felinoides.

\section{Material and methods}

\section{Nomenclature and measurements}

Dental nomenclature (Text-fig. 1) follows Ginsburg (1999). Anatomical descriptions are based on Schaller (2007). Measurements (Tab. 2) were made using Mitutoyo Absolute digital calliper to the nearest $0.1 \mathrm{~mm}$.

\section{Institutional abbreviations}

MNHL Musée des Confluences, Lyon, France

MNHN Muséum national d'Historie naturelle, Paris, France

MNCN Museo Nacional de Ciencias Naturales, Madrid, Spain

NMB Naturhistorisches Museum Basel, Basel, Switzerland

NMP National Museum, Prague, the Czech Republic (inv. no. NM-Pv)

TU Tuchořice locality, cast collection (housed in NMP and $\mathrm{MNCN}$ )

UCB Université Claude Bernard Lyon 1, Lyon, France

\section{Studied material}

The holotype, NM-Pv 11600 right mandible with c-p4$\mathrm{m} 1$, alveoli for m2-m3, of Peignecyon felinoides $\mathrm{n}$. gen. et n. sp. from Tuchořice (Pl. 1) is stored in the collections of NMP. The fossil associated described in the present work TU 73917 left mandible with p4-m2, alveoli p3 y m3 (P1. 2, Fig.1); TU 739137 left mandible fragment with p4 (Pl. 2, Fig. 2); TU 739118 left mandible with p4-m3 (Pl. 3, Fig. 1); TU 739115 right m1-m2 (Pl. 3, Fig. 2); TU 7391147 right p4-m2 (P1. 3, Fig. 3); TU 739111 right mandible with 
m1-m3 (Pl. 3, Fig. 4 ); TU 739151 left m2 (P1. 3 Fig. 5); TU 739110 right mandible with p4-m1; TU 739130 right P4 (Text-fig. 2a); TU 739129 right M1 (Text-fig. 2b); TU 739130 right M2 (Text-fig. 2c); TU 73916 right M1; 739136 left M2; TU 739151 left M2 (Text-fig. 2d) - are currently lost. The cast of these fossils are available in the collections of NMP and MNCN.

For systematic comparison and cladistics analysis, we have directly studied the following taxa: Ysengrinia gerandiana (VIRET, 1929a) and Cynelos lemanensis (PomeL, 1846) from Saint Gérand le Puy (France), early Miocene (MN 2) housed in MNHN and UCB; Thaumastocyon dirus GinsBURG et al., 1981 from Los Valles de Fuentidueña (Spain), late Miocene (MN 9) housed in MNCN; the undescribed dentition of Thaumastocyon n. $\mathrm{sp}$. from Batallones-3 (Spain), late Miocene (MN 10) housed in MNCN; Tomocyon grivensis VIRET, 1929b from La Grive Saint Alban (France), middle Miocene (MN 7/8) housed in UCB and MNHL; Ysengrinia valentiana BELINCHÓN et Morales, 1989 from Buñol (Spain), early Miocene (MN 4) by casts housed in MNCN; Thaumastocyon bourgeoisi Stehlin et Helbing, 1925 from Pont-Levoy (France), middle Miocene (MN 5) by casts housed in the MNHN; Daphoenodon superbus (PETERson, 1907) from Agate Fossil beds National Monument (USA) and Ysengrinia americana (WORTMAN, 1901) from Harrison Formation (USA), early Miocene (late Arikarean) by casts housed in MNCN.

\section{Cladistic analysis}

We performed a cladistic analysis to better assess the relationships between Peignecyon felinoides n. gen. et n. sp., and other amphicyonid taxa, such as the Oligocene Pseudocyonopsis spp. (Pseudocyonopsis antiquus GINSBURG, 1966, Pseudocyonopsis ambiguus (FILHol, 1876) and Pseudocyonopsis quercensis (GINSBURG, 1965)), the early Miocene Daphoenodon superbus, Cynelos lemanensis, Ysengrinia americana, Ysengrinia gerandiana, Ysengrinia valentiana and Crassidia intermedia (vON MEYER, 1849), the middle Miocene Tomocyon grivensis and Thaumastocyon bourgeosi, and the late Miocene Thaumastocyon sp. from Batallones 3 (Morales et al. 2017), together with the primitive carnivoran Paramiacis exilis (FILHOL, 1876). We excluded from the analysis some taxa related to the Thaumastocyoninae, such as Ysengrinia tolosana (Noulet, 1876), Ysengrinia depereti (MAYET, 1908), Thaumastocyon dirus and Agnotherium antiquum KAUP, 1833 because they are poorly represented, or there is no information on their upper dentition. The cladistics analysis includes 12 taxa and 36 equally weighted and unordered dental characters (21 binary characters and 15 multistate characters; see Tab. 1). Some of them were used by Viranta (1996) $(3,5,7,12,13$, 19, 23, 24 and 34) and by Peigné et al. (2008) (1, 3, 4, 5, 10, 22, 23, 24 and 33). The choice of characters was obtained from the molars (M1-M2 and $\mathrm{m} 2$ ) and the carnassial teeth $(\mathrm{P} 4 / \mathrm{m} 1)$. As information on the premolars is more limited, they play (except p4) a secondary role in the evolution of hypercarnivorous amphycyonids. The matrix can be observed in Table 3. We selected $P$. exilis as the outgroup. The analysis was performed with PAUP*4.0b10 (Swofford 2002).
Table 1. Character list and character states.

\begin{tabular}{|c|c|}
\hline 1 & Ratio LM2/LM1; >0.72 (0), between 0.72-0.62 (1), <0.62 (2) \\
\hline 2 & Ratio LM1/LP4; <0.76 (0), between 0.76-0.88 (1), >0.88 (2) \\
\hline 3 & P4 parastyle; small (0), strong (1), very developed (2) \\
\hline 4 & P4 protocone position; mesial (0), more distal (1) \\
\hline 5 & P4 protocone size; strong $(0)$, reduced (1) \\
\hline 6 & $\begin{array}{l}\text { P4 ratio W/L P4; >0.70 (1), between } 0.70-0.58(1), \\
<0.58(2)\end{array}$ \\
\hline 7 & M1 shape; subquadrangular (0), subtriangular (1) \\
\hline 8 & M1 paraconule; present (0), divided (1), reduced (2) \\
\hline 9 & $\begin{array}{l}\text { M1 metaconule; present (0), divided (1), enlarged (2), } \\
\text { reduced or lost (3) }\end{array}$ \\
\hline 10 & M1 paracone-metacone; low (0), high (1) \\
\hline 11 & M1 distal wall middle inflexion; present (0), absent (1) \\
\hline 12 & M1 protocone size; low/weak (0), high/strong (1) \\
\hline 13 & M1 protocone position; mesial (0), central (1) \\
\hline 14 & $\begin{array}{l}\text { M1 lingual cingulum position; distal /asymmetric (0), } \\
\text { distomesial/more symmetric (1) }\end{array}$ \\
\hline 15 & M1 lingual area; wide (0), narrowed (1) \\
\hline 16 & M1 lingual platform; large (0), reduced (1) \\
\hline 17 & M1 lingual cingulum; well developed (0), reduced (1) \\
\hline 18 & M1 ratio W/L; $<0.72(0)$, between $0.72-0.84(1),>0.84(2)$ \\
\hline 19 & M2 shape; short and large (0), oval (1) \\
\hline 20 & M2 ratio W/L; <0.62 (0), between $0.62-0.75(1),>0.75(2)$ \\
\hline 21 & M2 trigone cusp; differenciated (0), fused (1), reduced (2) \\
\hline 22 & Premolars (p1-p3); not reduced (0), reduced (1) \\
\hline 23 & Ratio Lm2/Lm1; >0.62 (0), <0.62 (1) \\
\hline 24 & m1 metaconid size; strong $(0)$, reduced or lost (1) \\
\hline 25 & m1 hypoconid; lateral $(0)$, central $(1)$ \\
\hline 26 & $\begin{array}{l}\text { m1 talonid - basal distobuccal expansion; absent (0), } \\
\text { present (1) }\end{array}$ \\
\hline 27 & $\mathrm{~m} 1$ ratio $\mathrm{W} / \mathrm{L} ;>0.60(0),<0.60(1)$ \\
\hline 28 & $\begin{array}{l}\mathrm{m} 2 \text { ratio } \mathrm{L} \text { talonid } / \mathrm{L} \text { trigonid; }>0.85(0) \text {, between } \\
0.85-0.68(1),<0.68(2)\end{array}$ \\
\hline 29 & $\mathrm{~m} 2$ ratio $\mathrm{W} / \mathrm{L} ;>0.60(0),<0.60(1)$ \\
\hline 30 & $\begin{array}{l}\text { m2 height of protoconid; protoconid > metaconid (0), } \\
\text { protoconid >> metaconid (1) }\end{array}$ \\
\hline 31 & m2 protoconid mesial cristid; oblique (0), rectilinear (1) \\
\hline 32 & m2 paraconid; present $(0)$, absent (1) \\
\hline 33 & m2 metaconid; present $(0)$, reduced or absent (1) \\
\hline 34 & m2 talonid; large (0), narrow (1) \\
\hline 35 & m2 hypoconid; small/buccal (0), enlarged/central (1) \\
\hline 36 & m2 buccal wall; almost vertical (0), basally expanded (1) \\
\hline
\end{tabular}

\section{Systematic palaeontology}

Order Carnivora Bowdich, 1821

Suborder Caniformia KRETzoI, 1943

Infraorder Arctoidea Flower, 1869

Family Amphicyonidae Trouessart, 1885

Subfamily Thaumasthocyoninae HürZELER, 1940

Diagnosis. Amphicyonidae presenting hypercarnivorous dentition, with reduced M2/m2-m3 and highly developed and sectorial carnassial teeth. Specialized genera with a reduction of the premolars and a large mandibular diastema, well-developed P4 parastyle and reduced M1 lingual area. 
Included genera. Thaumastocyon Stehlin et Helbing, 1925, Crassidia Heizmann et Kordikova, 2000, Ysengrinia GinsBurg, 1966, Tomocyon VIRET, 1929b and Peignecyon n. gen.

Remarks. The taxonomy and systematics of the Thaumastocyoninae amphicyonid have been considered to be quite complex since Hürzeler (1940), who described them as aberrant canids with feline tendencies. The latter author correctly characterized the subfamily based on the complete suppression of $\mathrm{ml}$ metaconid, reduction of the premolars, except the $\mathrm{p} 4$, which is reinforced, and the oblique abrasion of the teeth. He included in the group Thaumastocyon bourgeoisi, Agnotherium antiquum KAUP, 1833, Tomocyon grivensis VIRET, 1929b together with the amphicyonid remains from Frohnstteten, figured by Jäger (1835), unpublished materials housed in the Basel Museum (Switzerland) from Baigneaux-en-Beauce (France) and Chairmoille (Switzeland), and eventually, a mandible fragment from Steinheim (Germany), which was determined by Helbing (1929) as Pseudocyon sansaniensis LARTET, 1851 , and subsequently chosen as the holotype of a new subspecies, Pseudocyon sansaniensis serus Kuss, 1965 (Kuss 1965: 133).

Kuss (1962) performed the first in-depth review of the group, in which he proposed the inclusion of Tomocyon grivensis in Agnotherium. He considers that A. antiquum likely had upper molars with a non-reduced lingual area, an argument which favoured the determination of Frohnstetten fossils as $A$. antiquus, reconstructing the molar morphology with a strong development of the lingual area, using as a model the molars of T. grivensis (Kuss 1962: fig. 6). For some fossils from Baigneaux-en-Beauce, Kuss (1962: fig. 7) proposes their classification as Agnotherium grivensis (right m1; NMB S.O. 4459), aff. Agnotherium grivensis (for three P4; NMB S.O. 1274, 874 and 4460) and ?aff. Agnotherium grivensis (left M2; NMB S.O. 1559).

Ginsburg (1999) seconds this proposal, pointing out the presence of Agnotherium grivensis in Simorre (France) and Agnotherium antiquum in Pedregueras (Spain), and the presence of a second Thaumastocyon species, Th. dirus from Los Valles de Fuentidueña (Spain) (Ginsburg et al. 1981).

Heizmann and Kordikova (2000) erected the tribe Ysengrini to contain Crassidia, a new genus described in the same research, together with Ysengrinia and Amphicyonopsis VIRET, 1929b. For these authors, the Ysengrini occupies an intermediate position between Amphicyoninae and Thaumastocyoninae, but since the defining features of Thaumastocyoninae, loss of the $\mathrm{m} 1 \mathrm{metaconid}$ and shortening of the entire facial region, are not present in the Ysengrini, they consider them to constitute a specialized branch of the Amphicyoninae. But they did not take into account that both groups share other derived characters, which indicate a close relationship between them.

Amphicyonopsis was described by Viret (1929b) on the basis of $\mathrm{m} 1$ (MHNL LGR 1136) from La Grive (France), but no species was included in the new genus. Kuss (1965) included it, together with other teeth from La Grive as Pseudocyon sansaniensis aff. serus n. subsp. Heizmann (1973) considers that the holotype of this subspecies, the mandible fragment from Steinheim included by
Hürzeler (1940) within the Thaumastocyoninae, should be distinguished from Pseudocyon and attributed to Amphicyonopsis? serus (Kuss, 1965).

Mein and Ginsburg (2002), partially in accordance with Kuss (1965), transferred the fossils of La Grive to Pseudocyon sansaniensis and therefore excluded them from the Thaumastocyoninae.

Identification of Agnotherium and Ysengrinia in Africa is problematic, as has recently been discussed by Morales et al. (2016). For these authors, the African amphicyonids previously identified in these genera acquired their hypercarnivorous adaptation independent from the European taxa. This could be the case of Ysengrinia americana, as will subsequently be discussed. The Tuchořice Thaumastocyoninae are important, since they can help to identify the beginning of the more specialized Thaumastocyoninae, and because they are a significant link between these genera and the more primitive species included in the Ysengrini tribe by Heizmann and Kordikova (2000).

Thus, our paper accepts the presence of two tribes of Thaumastocyoninae in the late Oligocene/Miocene of Europe - Thaumastocyonini HüRZELER, 1940 which included the genera Thaumastocyon Stehlin et Helbing, 1925, Tomocyon Viret, 1929b and Peignecyon n. gen., and Ysengrini HeIZmannN et Kordikova, 2000 which included the genera Ysengrinia Ginsburg, 1966 and Crassidia HeIzMAnNn et Kordikova, 2000.

We did not consider some taxa, such as Amphicyonopsis serus (Kuss, 1965), which we believe to be a species of dubious validity, or Agnotherium antiquum KAUP, 1833, defined in Eppelsheim (MN 9), Germany, and only represented by one sectorial $\mathrm{m} 1$. This tooth displays an advanced degree of dental wear, which has partially erased its morphology. The paraconid mesial cristid is displaced lingually and is well marked, connecting to the basal lingual cingulum; the talonid is short and narrow with a high hypoconid and a reduced entoconid. These characters are associated with the hypercarnivorous tendency, and might likely have been acquired convergently in different Thaumastocyoninae taxa. The genera Thaumastocyon and Tomocyon present an $\mathrm{m} 1$ close to $A$. antiquus, but differ in their associated upper and lower teeth. We do not avail of any criteria to relate the Eppelsheim genus more closely to either one of these genera. Given our current knowledge, this $\mathrm{ml}$ is insufficient with regard to defining a genus, or even a species. Most of the Agnotherium antiquus published determinations have been indirect, based upon tooth size and sectorial morphology of specimens. This has given rise to multiple errors, as Kurtén (1976) initially pointed out. The determination of Agnotherium antiquus in Pedregueras 2A and Charmoille exemplify this circumstance; in both localities the material comprises a lower canine, $\mathrm{p} 4$ and $\mathrm{m} 1$; the $\mathrm{m} 1 \mathrm{~s}$ are morphologically close to the tooth of Eppelsheim, although the mesial paraconid-cristid is less marked. The canine and $\mathrm{p} 4$ present a similar morphology and robustness to those of La Grive homologous teeth (Viret 1929a: pl. 19, figs 3, 7). The conclusion is evident; there is a suite of features such as the advanced degree of $\mathrm{m} 1$ sectorialitation (loss of metaconid, talonid reduction, sharp cristid, etc.), the robustness of the lower canine and the $\mathrm{p} 4$, and others, which enable the Thaumastocyonini clade to be defined, but which 
by themselves do not permit an unequivocal determination within this taxon.

\section{Genus Peignecyon n. gen.}

Ty pe s pecies. Peignecyon felinoides n. sp.

E t y m o lo g y. In honour of the late Stéphane Peigné.

Type locality. Tuchorice, the Czech Republic.

A g e. Early Miocene (MN 3).

Diagnosis. Thaumastocyoninae presenting long mandible diastema, reduced mesial premolars (p2-p3), p4 with inclined distally high main cusp; sectorial carnassials, talonid and trigonid of $\mathrm{m} 1$ with similar width, relict $\mathrm{m} 1$ metaconid. Reduced M2 and $\mathrm{m} 2$.

Peignecyon felinoides $\mathrm{n}$. sp. Text-figs 1, 2, Pls 1-3

2003 Tomocyon nov. sp.; Fejfar et al., p. 167.

2016 Tomocyon (? nov. gen.), nov. sp.; Fejfar and Heizmann, p. 325 .

H o l o t y p e . NM-Pv 11600 right mandible with p4-m1, alveoli for m2-m3 (P1. 1), deposited in NMP.

P a r a ty pe. TU 73916 right M1 (Text-fig. 2b).

E t y m o lo g y. "felinoides" from feline, denomination used by Hürzeler (1940) for this group of Amphicyonidae.

Type locality. Tuchořice, the Czech Republic.

A g e. Early Miocene (MN 3).

D i a g n o s is. The same as for the genus.

D e s c r i p t i o n. Mandible and lower dentition. NMPv 11600 right mandible with c, p1 alveolus, p4-m1, and alveoli for $\mathrm{m} 2-\mathrm{m} 3$ (holotype, $\mathrm{Pl} .1$ ), the mandible is included in the sediment with the lingual wall exposed. The mandible ramus was partially broken, but the fragments remained close to the corpus mandibulae, and this part has thus been restored in the image (Pl. 1, Fig. 1a). The overall morphology is close to that of the wolf (Canis lupus), but is somehow shorter and more robust. There is a long diastema between the p4 and the alveolus for the $\mathrm{p} 1$ without the alveoli for $\mathrm{p} 2-\mathrm{p} 3$. The margo interalveolaris is sharp, and in lingual view it presents a concave profile (Pl. 1, Fig. 1a, b), common in species with premolar reduction and presence of a long diastema, as occurs in Thaumastocyon bourgeoisi (see Stehlin and Helbing 1925) or Pseudocyon? astrei Kuss, 1962. The canine associated with the mandible is well developed, and presents a sharp and irregularly crenulated distal cristid (P1. 1, Fig. 2). The $\mathrm{p} 4$ is small in relation to the $\mathrm{m} 1$, presenting a smooth paraconid. The protoconid is distally inclined, high and with a smooth mesial cristid. The distal cuspid is well individualized and the talonid is small. The lingual cingulum is somewhat more developed in the distal part of the tooth, where it is slightly expanded. The $\mathrm{m} 1$ is a sectorial tooth with moderately laterally compressed paraconid and protoconid. The paraconid mesial cristid is not totally vertical. The $\mathrm{m} 1$ metaconid is a small bulge in the middle of the distolingual protoconid cristid. The talonid is very short, and is mostly occupied by a tall and long hypoconid. The mesial cristid of
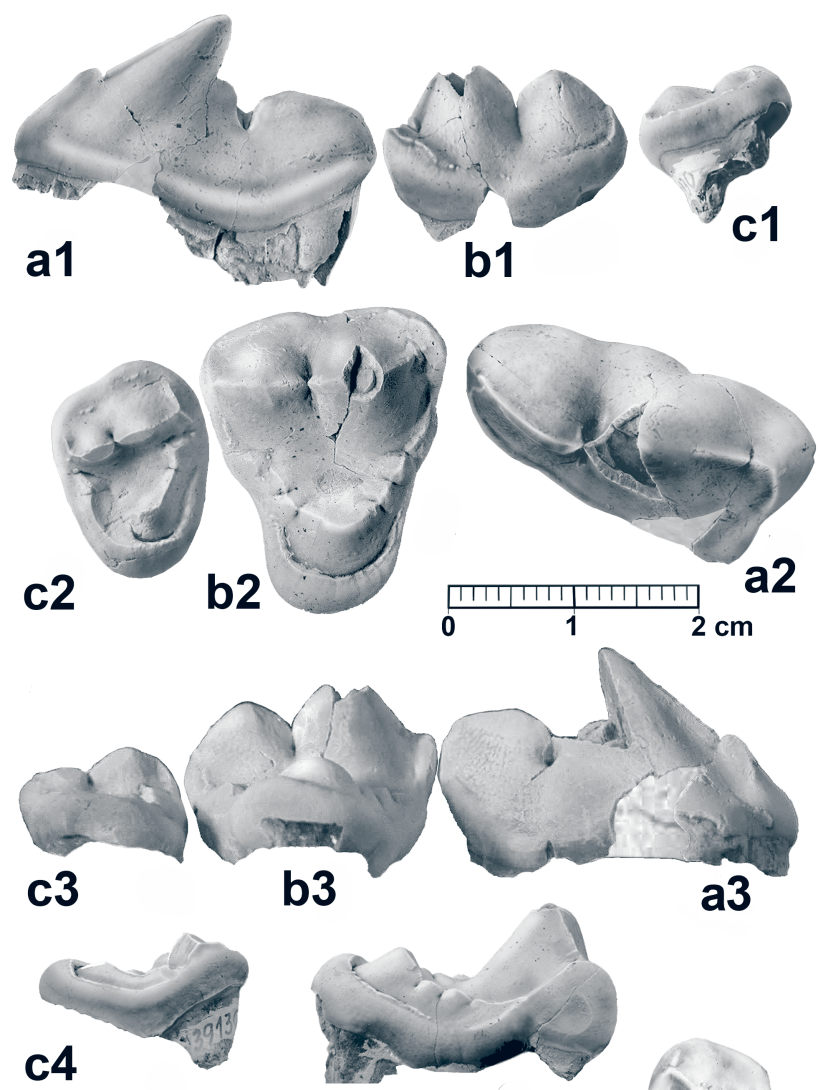

b4
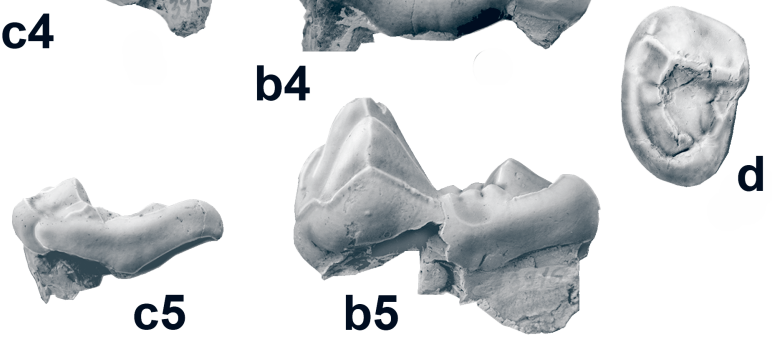

Text-fig. 2. Peignecyon felinoides n. gen. et n. sp., from Tuchořice, the Czech Republic. a) TU 739130 right P4; a1) buccal view, a2) occlusal view, a3) lingual view. b) TU 73916 right M1; b1) buccal view, b2) occlusal view, b3) lingual view, b4) mesial view, b5) distal view. c) TU 739130 right M2; c1) buccal view, c2) occlusal view, c3) lingual view, c4) mesial view, c5) distal view. d) TU 739151 left M2; occlusal view.

the hypoconid is aligned with those of the protoconid and paraconid, forming the carnassial blade. The entoconid is relatively large and located parallel to the hypoconid, and both cuspids are separated by a very narrow valley. A small cristid in the hypoconulid position connects the entoconid with the hypoconid. The $\mathrm{m} 2$ is missing, but the alveoli are seen to present a moderate size. The alveolus for the $\mathrm{m} 3$ is very small, with one single root.

TU 73917 left mandible with p4-m2 and alveoli for $\mathrm{p} 3$ and $\mathrm{m} 3$ (Pl. 2, Fig. 1). The presence of a possible p3 is marked by a one-rooted alveolus, separated from the $\mathrm{p} 4$ by a small diastema. Both the $\mathrm{p} 4$ and the $\mathrm{m} 1$ are morphologically close to the holotype. The $\mathrm{m} 1$ metaconid is reduced to a small notch in the distolingual cristid of the protoconid. The $\mathrm{m} 1$ talonid is also very short, with a small entoconid situated in its distolingual corner. The distal end of the talonid is rectilinear. The cingula are very smooth. There is a deep vertical occlusion facet in the labial wall, between 
the protoconid and the hypoconid, as well as vertical wear facets on the labial wall of both the paraconid and the protoconid. The $\mathrm{m} 2$ exhibits a quadrangular shape, with a complete trigonid, although the paraconid is low and very reduced. Its labial cristid connects the mesial cristid of the protoconid, and appears to be labially attached to the metaconid, in such a way that a well-defined mesiolingual valley is formed among them. The protoconid is quite large, with a pyramidal morphology; it has three cristids, one mesial, another distal (parallel to the molar axis) and the third one lingual, contacting the metaconid. Its labial wall is basally widened. The metaconid is smaller and lower than the protoconid, and is slightly displaced distally. The talonid is short, with a low and wide hypoconid. The entoconid is also low, and is located in the distolingual corner. Between these two cusps, a narrow and relatively deep valley can be observed. The cingula are smooth. The presence of a small $\mathrm{m} 3$ is attested by a small distal alveolus, partially broken. The $\mathrm{m} 3$ is represented in some specimens TU 739118 ( $\mathrm{Pl}$. 3, Fig. 1), TU739111 (Pl. 3, Fig. 4); it is morphologically close to the $\mathrm{m} 2$, but with less defined cuspids and an overall smaller size.

Some morphological variations can be recognized in other specimens; for example, TU 7391147, a right mandible (Pl. 3, Fig. 3), lacks the parastylid in the p4 and its distal cusp is somewhat stronger; the $\mathrm{m} 1$ retains a small metaconid, and the mesial cristid of the paraconid is slightly displaced lingually and highly marked. Furthermore, the labial wall of the hypoconid is somewhat basally expanded, developing an incipient cingulum. The $\mathrm{m} 2$ represents quite a different morphotype, in particular due to the greater reduction of the talonid, which is almost exclusively built by the hypoconid; this morphology is also observed in the left $\mathrm{m} 2$ TU 939151 (Pl. 3, Fig. 5). The $\mathrm{m} 1$ of the specimen TU 739111 (Pl. 3, Fig. 4) has a small metaconid, but better developed than that of the previously mentioned specimens, as occurs with the mesial cristid of the paraconid, which is well-marked and tends to be in a more lingual position.

Upper dentition. TU 739130 right P4, elongated upper carnassial (Text-fig. 2a). The paracone and protocone are partially broken. There is a well-developed lingual cingulum. The parastyle is present and individualized, but still moderate

Table 2. Measurements (in $\mathbf{m m}$ ) of the lower teeth and upper teeth of Peignecyon felinoides $n$. gen. et $n$. sp., from Tuchořice, the Czech Republic. Abbreviations: L - antero-posterior diameter, W - width, *estimated measure, **alveolus measure.

\begin{tabular}{|c|c|c|c|c|c|c|c|}
\hline Lower teeth & Lp4 & Wp4 & Lm1 & Wm1 & Lm2 & Wm2 & Lm3 \\
\hline TU 739115 & 14.2 & $7.3 *$ & 27.9 & $12.5^{*}$ & $12 * *$ & & $8 * *$ \\
\hline TU 73917 & 14.9 & 7.9 & 27 & 12 & 15.4 & 11.2 & \\
\hline TU 739118 & & & 30 & 13.6 & & & \\
\hline TU 7391147 & 16.2 & 8.2 & 29.3 & 13.2 & 14.4 & 10.8 & \\
\hline TU 739115 & & & 27.3 & 12.6 & 15.5 & 11.2 & \\
\hline Upper teeth & LP4 & WP4 & LM1 & WM1 & LM2 & WM2 & \\
\hline TU 739130 & 29.6 & $14.8^{*}$ & & & 12.9 & 17.7 & \\
\hline TU 73916 & & & 20.4 & 24.8 & & & \\
\hline TU 739129 & & & $19.1 *$ & 23.6 & & & \\
\hline TU 739136 & & & & & 11.2 & 15.9 & \\
\hline
\end{tabular}

in size. The protocone appears to be reduced, and its position is somewhat distal. The paracone is coniform, with a very marked mesial crista presenting a clear distal inclination. The metastyle is quite robust.

TU 73916 right M1 (Text-fig. 2b). The occlusal outline is an isosceles triangle with the labial wall rectilinear, with a smooth ectoflexus. The parastyle is quite well developed. The paracone is rather larger and higher than the metacone. The metastyle is small. The labial cingulum is high and strong at the base of both the paracone and metacone, but weaker in the ectoflexus area. The paraconule and the metaconule are subdivided and well developed. The paraconule comes into contact with a high cingulum, developed from the parastyle, whereas the metaconule connects with a small cusp associated with the metastyle cingulum, which is very weak lingually. The protocone is situated in a central position relative to the labial wall; it is strong, with a duniform shape and completely encircled by a strong labial cingulum, which reaches the bases of the paraconule and metaconule. It is thickened at its distolingual corner. The lingual part of the molar is clearly reduced compared to the labial one. In the distal wall there is a strong inflexion at the position of the metaconule, while the mesial wall is more rectilinear. The central valley of the trigone is deep, revealing a circular wear pattern in the centre, resulting from the occlusion with the $\mathrm{m} 1$ hypoconid. An additional right M1, TU 739129, is poorly preserved; it is somewhat smaller but morphologically similar to the other molar.

TU 739130 right M2 (Text-fig. 2c). It presents an oval shape and small size in relation to the M1. Its basal cingulum surrounds the complete molar, thickening at the distolingual corner. Both the paracone and the metacone are low and somewhat lingually displaced. Both parastyle and metastyle are small. The protocone is poorly developed; it is located in a central position and joined by a long crista to the paraconule. The metaconule is included in the distal cingulum, and does not make contact with the protocone. There is a small cusp lingual to the metacone, associated with the metastyle. The trigone valley is broad and flat. Specimen TU 739136 is also an M2, which is similar in shape to TU 739130, but smaller in size (Text-fig. 2d).

Discussion. The hypercarnivorous character of Peignecyon felinoides is unquestionable; it is manifested in the strong development of the sharp mandibular diastema, associated with the reduction of the anterior premolars, p4 high, with a distally inclined mesial cristid, carnassials with sectorial morphology, characterized by the reduction of the $\mathrm{ml}$ metaconid and the strong development of the hypoconid, and in the elongation of P4 with an incipient parastyle. The M1 presents a triangular occlusal shape and a very reduced lingual area. The second molars, $\mathrm{m} 2$ and $\mathrm{M} 2$, respectively, are smaller in relation to the $\mathrm{m} 1$ and M1. Some of these characteristics are also found in Ysengrinia gerandiana (Viret 1929a, Ginsburg 1965) from Saint Gérand le Puy (France), early Miocene (MN 2). However, in the latter species, these hypercarnivorous characters are less developed. Among other traits, it possesses a less reduced lower premolar row with shorter diastemas; the p4 has the principal cusp smaller and more vertical, with no distal inclination of the mesial cristid; the $\mathrm{m} 1$ is more robust 
and retains a strong metaconid. Additionally, the talonid is wider than the trigonid, and its hypoconid and entoconid are comparatively less developed. These differences between both amphicyonids are noteworthy, and suggest a clear taxonomic separation between them.

Peignecyon felinoides differs from other species included in the genus Ysengrinia, such as Ysengrinia tolosana (Noulet, 1876) and Ysengrinia depereti (MAYET, 1908), in its smaller dentition, a more gracile $\mathrm{m} 1$ with a more reduced metaconid, and the $\mathrm{m} 2$, which has lower and smaller cuspids. The absence of upper dentition for these taxa severely limits the comparisons. However, the differences in relation to $P$. felinoides are more pronounced than those indicated for Y. gerandiana.

The species Ysengrinia americana (WoRTMAN, 1901) is much better represented; it was originally described as Amphicyon, and included by Hunt (2002) in this European genus. The relationship between European and American species has been exhaustively discussed by this author, who finds obvious affinities between $Y$. americana and $Y$. tolosana, and between the latter two and $Y$. gerandiana. However, there are notable differences in the upper dentition, which obscure these relationships. The M1 of Ysengrinia americana shows a strong reduction of the lingual area, similar to that observed in Y. gerandiana and $P$. felinoides, but the lingual cingulum does not completely encircle the protocone as it does in these two European species. On the contrary, this cingulum is restricted to the distolingual margin, so that the mesial wall of the protocone forms part of the wall itself, and its cingulum is only a small ridge. Additionally, the M1 of $P$. felinoides has buccal cusps that are much higher than in the American species, and the paraconule and metaconule are coniform and subdivided, whereas in $Y$. americana they form crests and are attached to the protocone. In the M2, the differences are even more pronounced; in $Y$. americana the molar is morphologically close to the M1, but the protocone is completely surrounded by the lingual cingulum, which is comparatively better developed. In Y. gerandiana and P. felinoides, the M2 is very reduced lingually, and the molar is therefore oval, and the protocone is very reduced. Thus, in both European species, the M2 has a similar overall shape of the M3 to Y. americana and other amphicyonid species. This fact can be related to the strong tendency of $Y$. gerandiana and $P$. felinoides to reduce the crushing molar, whilst in $Y$. americana, this feature is less pronounced. The lower dentition of $P$. felinoides also differs from that of $Y$. americana in the greater gracility of the p4 and the m1. Considering the current data, we conclude that $Y$. americana cannot be included within the genus Ysengrinia. Consequently, Y. tolosana and $Y$. depereti, only represented by their lower dentition, also remain in an uncertain systematic position, awaiting documentation on their upper dentition.

Although in our analysis, $Y$. americana could be considered as the sister group of the Thaumastocyoninae (Text-fig. 3), alternatively, it could be related to other hypercarnivorous Amphicyoninae that have retained a well-developed M2 and a reduced p4 (Peigné et al. 2008, Morales et al. 2016). These Amphicyoninae require an indepth taxonomic and systematic review, but this is not the objective of the present paper.
A second genus Crassidia was included close to Ysengrinia in the Ysengrini tribe by Heizmann and Kordikova (2000). Peignecyon felinoides differs from other species grouped in the genus Crassidia (Heizmann and Kordikova $2000)$ in the general gracility of its dentition. Significant differences are also seen in the morphology of the M1, which in the holotype of Crassidia intermedia from Ulm has a very developed lingual area, as occurs in the maxilla fragment of Selles-sur-Cher (Heizmann and Kordikova 2000: pl. 6); this specimen shows the presence of an M2, which despite the buccal wall being broken, is large and shows a subquadrated occlusal shape, in which the major axis is buccolingual, as is characteristic of $Y$. americana. Crassidia intermedia appears in our phylogenetic analysis (Text-fig. 3) as the sister group of the rest of the Thaumastocyoninae, close to $Y$. gerandiana. Peignecyon felinoides differs from these two genera in a suite of advanced features, such as the loss of the $\mathrm{m} 1$ metaconid and the strong reduction of the M1 lingual area, which it shares with the most specialized Thaumastocyoninae genera, Tomocyon and Thaumastocyon.

Tomocyon grivensis from the late middle Miocene of $\mathrm{La}$ Grive (France) differs from $P$. felinoides in the following characters: a p4 exhibiting a higher protoconid and a much stronger distal cingulum; m1 long, with a sharp mesial paraconidcristid, and buccolingually compressed, like the protoconid and talonid. The distolingual cristid of the protoconid is very prominent and has no metaconid, while the hypoconid has a strong basal cingulum extending distally beyond the distal edge of the tooth; in the $\mathrm{m} 2$ the metaconid is located distally to the very large and high protoconid, so that the trigonid valley is reduced and mesio-lingually located, the talonid is narrow and similar to what it is observed in the $\mathrm{m} 1$, the base of the hypoconid is distally expanded; the P4 is longer, with a strong parastyle and a more distal protocone; the M1 exhibits a wider lingual area; consequently, its occlusal shape is subquadrangular, the paracone is much higher and more developed than the metacone, the metaconule is poorly differentiated and the lingual cingulum is stronger, especially in the distolingual corner; in the $\mathrm{m} 2$ the protocone connects both the metaconule and the paraconule, forming a continuous semicircular crista, which joins the buccal cingulum. Many of these differences indicate that T. grivensis possesses a better developed sectorial dentition compared to that of $P$. felinoides. However, in the M1, it presents a larger lingual area in contrast to the reduction observed in the Thaumastocyon species; this is also observed in the $\mathrm{m} 2$, which retains a relatively large size.

The other genus is Thaumastocyon, with two species, Th. bourgeoisi (type species) from the middle Miocene (MN 5) and Th. dirus from the late Miocene (MN 9) of Spain (Ginsburg et al. 1981). As we have already pointed out, Thaumastocyon is characterized by extreme reduction of the M1 lingual cingulum feature, which is absent in all the other members of this subfamily. The holotype of Th. bourgeoisi Sthelin et Helbing, 1925 is a mandible (PontLevoy 69) preserving the canine and the $\mathrm{m} 1-\mathrm{m} 2$. The $\mathrm{m} 1$ has more compressed buccolingual cuspids than those of $P$. felinoides; moreover, the reduction of the metaconid is complete, although a tiny notch in the distolingual cristid marks its ancestral position; the distobuccal base of the hypoconid is more swollen and projected distally. 


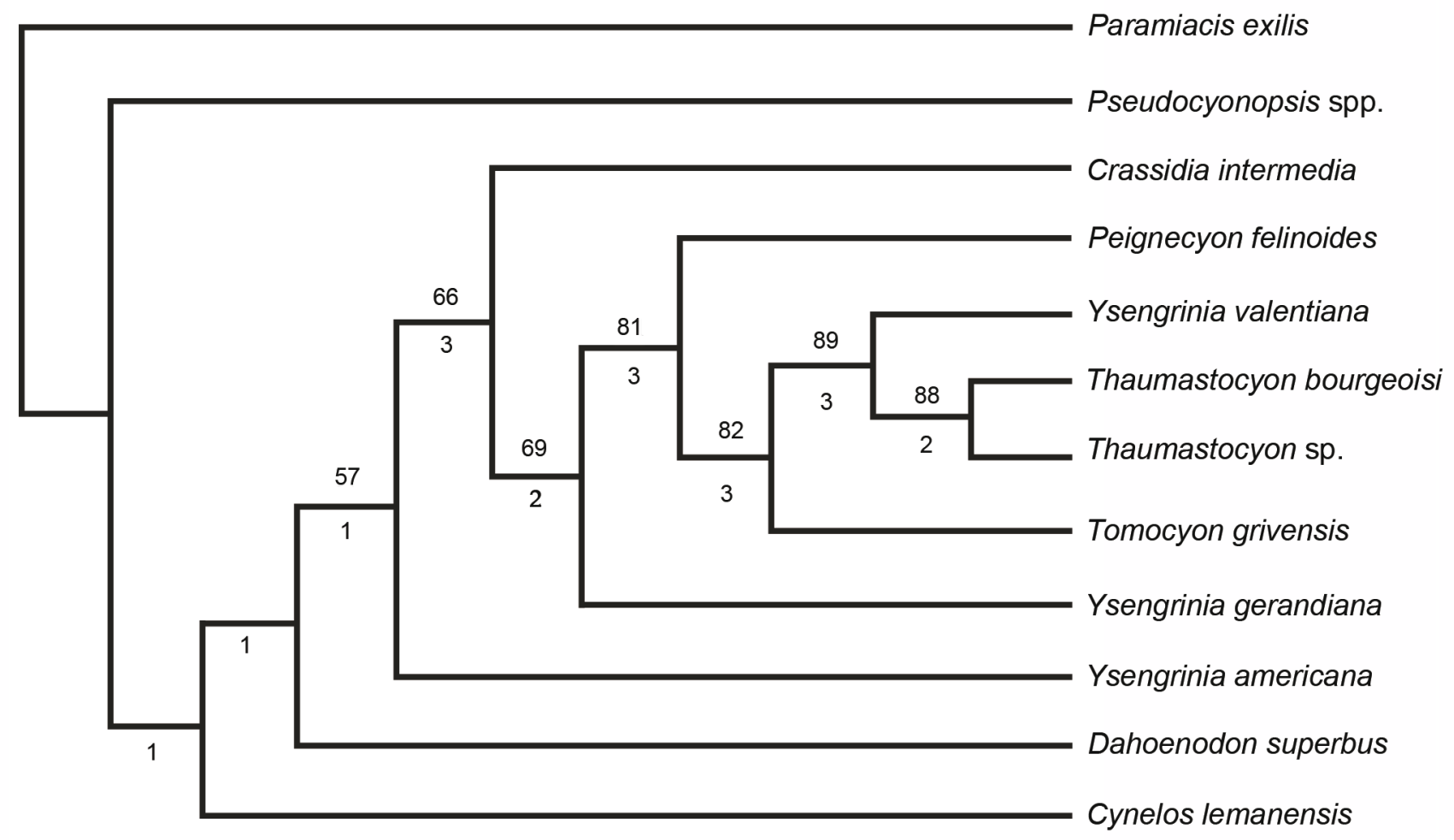

Text-fig. 3. Phylogenetic relationship of Peignecyon felinoides n. gen. et n. sp., within some selected Amphicyonidae, and some extinct caniform carnivorans. Paramiacis exilis is the outgroup. Searches were performed by means of the Branch and Bound and a Bootstrap analysis through 1,000 replicates. One tree is obtained (length 73 steps, consistency index $(\mathrm{CI})=0.6301$, retention index $(\mathrm{RI})=0.7000)$. The numbers below nodes are Bremer indices, and the numbers above nodes are Bootstrap support percentages (only shown $\geq 50$ ).

The $\mathrm{m} 2$ is morphologically similar to the morphotype, of Tuchořice, which presents a reduced talonid. Furthermore, Thaumastocyon dirus is somewhat larger, and differs from the type species of the genus in the almost total loss of the M1 lingual cingulum.

Ysengrinia valentiana from the locality of Buñol (Spain), early Miocene (MN 4) (Belinchón and Morales 1989) is quite interesting, although the species is represented by only two teeth: a left M1 (smaller in size that the M1 of P. felinoides), which displays a reduced lingual area, with a weak lingual cingulum distally placed. The protocone, although still in a central position, presents a mesial crista that forms part of the mesial wall, similar to that of $Y$. americana. Additionally, the reduction of the labial cingulum, with the consequent buccolingual shortening of the molar, clearly differentiates $Y$. valentiana from the American species. The second tooth of $Y$. valentiana, left $\mathrm{m} 2$, is morphologically close to that of $P$. felinoides (mandible TU 73917; P1. 2, Fig. 1); it presents a strong wear facet in the mesiobuccal corner, which perfectly fits with a wear facet on the lingual wall of the M1 metacone. In $Y$. valentiana, the molar morphology is close to Thaumastocyon bourgeoisi, but the Spanish species still retains a larger M1 lingual cingulum. At least regarding the M1, Y. valentiana certainly appears to occupy an intermediate position between $P$. felinoides and
Th. bourgeoisi, although we have very little material to ascertain its systematic position.

\section{Phylogenetic approach}

Our cladistics analysis recovers a major clade: the Thaumastocyoninae, comprising Crassidia intermedia, Ysengrinia gerandiana, Peignecyon felinoides, Tomocyon grivensis, Ysengrinia valentiana and Thaumastocyon spp., is relatively well supported (Text-fig. 3). The subfamily Thaumastocyoninae is characterized by the start of an m2/M2 reduction, still moderate in Crassidia intermedia, but remarkable in the other species of the clade. In successive dichotomies, gradual progress can be observed towards the development of hypercarnivorous dentition. First, it is manifested in the specialization of the carnassial teeth, with the reduction of the $\mathrm{P} 4$ protocone and the $\mathrm{m} 1$ metaconid. Next is the appearance of Peignecyon felinoides, which already shows the advanced features defining the group, such as the loss of the $\mathrm{m} 1$ metaconid and the strong reduction of the M1 lingual area. This species appears as the sister group of Tomocyon and Y. valentiana + Thaumastocyon spp. Consequently, it can be considered to constitute a link between these taxa, and $Y$. gerandiana and C. intermedia. Apparently, Tomocyon grivensis has retained this intermediate grade 
Table 3. Character matrix of the taxa analysed (see Table 1 for the corresponding list of characters and character states).

Taxon / Character
Paramiacis exilis
Pseudocyonopsis spp.
Crassidia intermedia
Peignecyon felinoides
Ysengrinia valentiana
Ysengrinia gerandiana
Ysengrinia americana
Tomocyon grivensis
Thaumastocyon bourgeoisi
Thaumastocyon sp.
Daphoenodon superbus
Cynelos lemanensis

\begin{tabular}{|l|l|l|l|l|l|l|l|l|l|l|l|}
\multicolumn{10}{|c|}{ I } \\
\hline 0 & 0 & 0 & 0 & 0 & 0 & 0 & 0 & 0 & 0 & 0 & 0 \\
\hline 2 & 0 & 0 & 0 & 0 & 2 & 1 & 0 & 0 & 0 & 1 & 1 \\
\hline 2 & $?$ & 2 & 0 & 0 & 1 & 1 & 0 & 0 & 1 & 1 & 1 \\
\hline 2 & 0 & 1 & 0 & 1 & 2 & 1 & 1 & 1 & 1 & 0 & 1 \\
\hline$?$ & $?$ & $?$ & $?$ & $?$ & $?$ & 1 & 2 & 3 & 1 & 0 & 1 \\
\hline 2 & 1 & $?$ & $?$ & $?$ & 2 & 1 & $?$ & $?$ & $?$ & 0 & 0 \\
\hline 1 & 1 & 0 & 0 & 0 & 1 & 1 & 0 & 0 & 0 & 0 & 0 \\
\hline 2 & $?$ & 2 & 1 & 1 & 2 & 0 & 1 & 2 & 1 & 0 & 1 \\
\hline$?$ & $?$ & $?$ & $?$ & $?$ & $?$ & 1 & 2 & 3 & 1 & 0 & 1 \\
\hline 2 & 0 & 2 & 1 & 0 & 2 & 1 & $?$ & $?$ & $?$ & $?$ & 1 \\
\hline 1 & 1 & 0 & 0 & 0 & 1 & 1 & 0 & 0 & 0 & 1 & 0 \\
\hline 1 & 1 & 0 & 0 & 0 & 1 & 0 & 0 & 1 & 0 & 1 & 0 \\
\hline
\end{tabular}

Taxon / Character
Paramiacis exilis
Pseudocyonopsis spp.
Crassidia intermedia
Peignecyon felinoides
Ysengrinia valentiana
Ysengrinia gerandiana
Ysengrinia americana
Tomocyon grivensis
Thaumastocyon bourgeoisi
Thaumastocyon sp.
Daphoenodon superbus
Cynelos lemanensis

\begin{tabular}{|l|l|l|l|l|l|l|l|l|l|l|l|}
\multicolumn{10}{|c|}{15} \\
\hline 0 & 0 & 0 & 0 & 0 & 0 & 0 & 0 & 0 & 0 & 0 & 0 \\
\hline 1 & 0 & 0 & 0 & 0 & 0 & 0 & 0 & 0 & 0 & 0 & 0 \\
\hline 1 & 1 & 0 & 1 & 0 & 1 & 0 & $?$ & 0 & 0 & 1 & 0 \\
\hline 1 & 1 & 1 & 1 & 0 & 1 & 1 & 1 & 2 & 1 & 1 & 1 \\
\hline 1 & 0 & 1 & 1 & 1 & 1 & $?$ & $?$ & $?$ & $?$ & $?$ & $?$ \\
\hline 1 & 1 & 1 & 1 & 0 & 2 & 1 & 1 & 1 & 0 & $?$ & 0 \\
\hline 0 & 0 & 1 & 0 & 0 & 1 & 0 & 1 & 0 & 1 & 1 & 0 \\
\hline 0 & 0 & 0 & 1 & 0 & 1 & 1 & 1 & 1 & 1 & $?$ & 1 \\
\hline 1 & 0 & 1 & 1 & 1 & 2 & $?$ & $?$ & $?$ & 1 & 1 & 1 \\
\hline 1 & $?$ & 1 & 1 & 1 & 2 & $?$ & $?$ & $?$ & 1 & 1 & 1 \\
\hline 0 & 0 & 1 & 0 & 0 & 1 & 0 & 1 & 0 & 0 & 2 & 0 \\
\hline 0 & 0 & 0 & 0 & 0 & 1 & 0 & 2 & 0 & 0 & 1 & 0 \\
\hline
\end{tabular}

\begin{tabular}{|c|c|c|c|c|c|c|c|c|c|c|c|c|}
\hline Taxon / Character & & & & & & & & & & & & \\
\hline Paramiacis exilis & 0 & 0 & 0 & 0 & 0 & 0 & 0 & 0 & 0 & 0 & 0 & 0 \\
\hline Pseudocyonopsis spp. & 1 & 0 & 1 & 0 & 0 & 0 & 0 & 0 & 0 & 1 & 1 & 0 \\
\hline Crassidia intermedia & $?$ & 0 & 1 & 1 & 0 & 0 & 1 & 1 & 0 & 1 & 1 & 0 \\
\hline Peignecyon felinoides & 1 & 0 & 1 & 1 & 0 & 0 & 1 & 0 & 0 & 0 & 0 & 0 \\
\hline Ysengrinia valentiana & $?$ & $?$ & $?$ & $?$ & 0 & 1 & 1 & 1 & 1 & 1 & 0 & 0 \\
\hline Ysengrinia gerandiana & 1 & 0 & 1 & 1 & 0 & 0 & 0 & 1 & 0 & 0 & 1 & 0 \\
\hline Ysengrinia americana & 1 & 0 & 1 & 1 & 0 & 0 & 1 & 1 & 0 & 1 & 1 & 0 \\
\hline Tomocyon grive & 1 & 1 & 1 & 1 & 0 & 1 & 1 & 1 & 0 & 1 & 0 & 0 \\
\hline Thaumastocyon bourgeoisi & 1 & 1 & 1 & 2 & 0 & 1 & 1 & 1 & 1 & 1 & 1 & 0 \\
\hline Thaumastocyon sp. & 1 & 1 & 1 & 2 & 1 & 1 & 1 & 1 & 1 & 1 & 1 & 0 \\
\hline Daphoenodon superbus & 0 & 0 & 1 & 0 & 0 & 0 & 0 & 0 & 0 & 0 & 0 & 0 \\
\hline Cynelos lemanensis & 0 & 0 & 1 & 0 & 0 & 0 & 0 & 0 & 0 & 0 & 0 & 0 \\
\hline
\end{tabular}

characterizing $P$. felinoides, although some of the $\mathrm{m} 1$ from La Grive show significant size development, associated with prominent and cutting cristids. Nevertheless, $Y$. valentiana displays a more advanced reduction of the crushing molars, with an $\mathrm{m} 2$ talonid and M1 lingual area reduced in size. This trend is even more evident in Th. bourgeosi, whose M1 barely retains a tiny lingual cingulum, which is completely lost in $T h$. dirus, so that the molar comprises only the trigone, in which the protocone is quite small. However, the clade comprising Y. valentiana + Thaumastocyon spp. + Tomocyon is better supported by bootstrap results and Bremer indices (Text-fig. 3). Other characters associated with the hypercarnivorous adaptation are less documented, but the final result is close to the more hypercarnivorous species of the mammalian fossil record, but constrained by the retention of a talonid in the $\mathrm{m} 1$, and consequently the presence of a protocone in the M1.

Ysengrinia appears in the analysis as a polyphyletic genus (Text-fig. 3). The type species Ysengrinia gerandiana is placed relatively close to $P$. felinoides, although the latter in a more advanced node than that of the French species. Ysengrinia valentiana could possibly be better classified as Thaumastocyon than as Ysengrinia, but there is a need for additional material to confirm this hypothesis. Ysengrinia americana is also classified separately from the other Ysengrinia species considered in the analysis; its classification to the genus Ysengrinia is problematic, as we have previously discussed. Moreover, our phylogenetic hypothesis supports a sister relationship between Thaumastocyoninae and Y. americana, although support for this hypothesis is low (Text-fig. 3). Another species included in the analysis, Daphoenodon superbus, is placed close to $Y$. americana, but presents certain more plesiomorphic characters, retaining a complete premolar row showing no teeth size reduction, a short $\mathrm{P} 4$ with strong mesial protocone or a large M1 (Hunt 1998); however, it also presents a notable size reduction of $\mathrm{M} 2-\mathrm{M} 3 / \mathrm{m} 2-\mathrm{m} 3$, which could indicate a clear divergence between them. Cynelos lemanensis represents a species with no hypercarnivorous characters in the dentition, and shows an opposite trend to Thaumastocyoninae and other taxa included in the analysis; this species tends to increase the crushing surface of the molars. Finally, Pseudocyonopsis spp. appears far from the Thaumastocyoninae species and consequently, the similarities with Ysengrinia gerandiana are only the result of shared plesiomorphic characters.

\section{Acknowledgements}

We would like to thank the curators and collection managers of all the institutions visited. We also wish to thank Dr. Robert M. Hunt Jr. (University of Nebraska State Museum) for providing casts of Ysengrinia americana and Daphonoedon superbus.

O. F. and J. W. were granted funding by the Ministry of Culture of the Czech Republic (DKRVO 2019-2023/2.V.a, National Museum, 00023272). The Spanish Research Projects CGL 2015-68333-P and CGL2016-76431-P (MINECO/ FEDER-UE), the Research Groups CSIC 641538 and CAM-UCM 910607, and the Generalitat de Catalunya (CERCA Programme, and Beatriu de Pinós contract 2017 BP 00223 from AGAUR to J.A.) also funded aspects of this research. Additionally, this research received support from the SYNTHESYS Project http://www.synthesys.info/, which is financed by European Community Research Infrastructure Action under the FP7 "Capacities" Program under the grant agreement (SYNTHESYS; CZ-TAF-3329) of J.A. The support of the DST-NFR Centre of Excellence in Palaeosciences (CoE-Pal) toward this research for A. V. (COE2018-09POST and COE2019-PD07) is hereby acknowledged. Opinions expressed and conclusions reached are those of the author and are not necessarily to be attributed to the CoE.

We also thank Louis de Bonis and Gennady Baryshnikov for helpful reviews of the manuscript.

\section{References}

Belinchón, M., Morales, J. (1989): Los carnívoros del Mioceno inferior de Buñol (Valencia, España) [The carnivores of the early Miocene of Buñol (Valencia, Spain)]. - Revista de Paleontología, 4: 3-8. (in Spanish) 
Bonis, L. de (1966): Sur l'évolution du genre Haplocyon Schlosser (Carnivora). - Bulletin de la Société Géologique de France, 8: 114-117.

Bowdich, T. E. (1821): An Analysis of the Natural Classifications of Mammalia, for the Use of Students and Travellers. - printed by J. Smith, Paris, 115 pp.

Dehm, R. (1950): Die Raubtiere aus dem Mittel-Miocän (Burdigalium) von Wintershof-West bei Eichstätt in Bayern. - Bayerische Akademie der Wissenschaften, Mathematisch-naturwissenschaftliche Klasse, Abhandlungen, N. F., 58: 1-141.

Fejfar, O., Dvořák, Z., Kadlecová, E. (2003): New record of Early Miocene (MN3a) mammals in the open brown coal pit Merkur, North Bohemia, Czech Republic. - In: Reumer, J. W. F., Wessels, W. (eds), Distribution and Migration of Tertiary mammals in Eurasia. A volume in honour of Hans de Bruijn. DEINSEA, 10: 163-182.

Fejfar, O., Heizmann, E. (2016): An illustrated summary of the lower Miocene carnivores (Mammalia, Carnivora) of Tuchořice, Czech Republic. - Historical Biology, 28: 316-329. https://doi.org/10.1080/08912963.2015.1029923

Filhol, H. (1876): Mammifères fossiles nouveaux provenant des dépôts de phosphate de chaux du Quercy. - Comptes rendus hebdomadaires des Séances de l'Académie des Sciences, Paris, 82: 288-289.

Flower, W. H. (1869): On the value of the characters of the base of the cranium in the classification of the Order Carnivora and the systematic position of Bassaris and other disputed forms. - Proceeding of the Zoological Society of London, 1869: 4-37.

https://doi.org/10.1111/j.1469-7998.1869.tb07286.x

Ginsburg, L. (1965): “L'Amphicyon ambiguus" des Phosphorites du Quercy. - Bulletin du Muséum National d'Histoire Naturelle, 37: 724-730.

Ginsburg, L. (1966): Les amphicyons des phosphorites du Quercy. - Annales de Paléontologie, 52: 23-64.

Ginsburg, L. (1977): Les carnivores du Miocène de Beni Mellal. - Géologie Méditerranéenne, 4: 225-240. https://doi.org/10.3406/geolm.1977.1005

Ginsburg, L. (1999): Order Carnivora. - In: Rössner, G. E., Heissig, K. (eds), The Miocene Land Mammals of Europe. Friedrich Pfeil, München, pp. 109-148.

Ginsburg, L., Morales, J., Soria, D. (1981): Nuevos datos sobre los carnívoros de los Valles de Fuentidueña (Segovia) [New data on the carnivores of the Valles de Fuentidueña (Segovia)]. - Estudios Geológicos, 37: 383-415. (in Spanish)

Heissig, K., Fejfar, O. (2007): Die Säugetiere aus dem Untermiozän von Tuchořice in Nordwestböhmen - I. Die fossilen Nashörner (Mammalia, Rhinocerotidae). - Acta Musei Nationalis Pragae, Series B - Historia Naturalis, 63: 19-64.

Heizmann, E. P. J. (1973): Die Carnivoren des Steinheimer Beckens. B. Ursidae, Felidae, Viverridae, sowie Ergänzungen und Nachtrage zu den Mustelidae. - Palaeontographica, Suppl.-Bd. 8: 1-95.

Heizmann, E. P. J., Kordikova, E. G. (2000): Zur systematischen Stellung von „Amphicyon“ intermedius H. v. MeYER, 1849 (Carnivora, Amphicyonidae). - Carolinea, 58: 69-82.
Helbing, H. (1929): Pseudocyon sansaniensis Lartet von Steinheim am Albuch. - Eclogae Geologicae Helvetiae, 22: $180-184$.

Hough, J. (1948): A systematic revision of Daphoenus and some allied genera. - Journal of Paleontology, 22: 573600.

Hunt, R. M., Jr. (1998): North American Tertiary Amphicyonidae. - In: Janis, C. M., Scott, K. M., Jacobs, L. L. (eds), Evolution of Tertiary Mammals of North America. Volume 1: Terrestrial Carnivores, Ungulates, and Ungulatelike Mammals. Cambridge University Press, Cambridge, pp. 196-227.

Hunt, R. M., Jr. (2002): Intercontinental migration of Neogene amphicyonids (Mammalia, Carnivora): appearance of the Eurasian beardog Ysengrinia in North America. American Museum Novitates, 3384: 1-53. https://doi.org/10.1206/0003-0082(2002)384<0001:IMONAM>2.0.CO;2

Hürzeler, J. (1940): Über felinoide Caniden des europäischen Miocäns (Vorläufige Mitteilung). - Verhandlungen der Schweizerischen Naturforschenden Gesellschaft, 1940: 229-230.

Jäger, G. F. (1835): Übersicht der fossilen Säugethiere, welche in Württemberg in verschiedenen Formationen aufgefunden worden sind. - Carl Erhard, Stuttgart, 70 pp.

Kaup, J. J. (1833): Description d'ossements fossiles de mammifères inconnus jusqu'à présent, qui se trouvent au Muséum grand-ducal de Darmstadt. Second cahier. J. G. Heyer, Darmstadt, 31 pp.

Kretzoi, M. (1943): Kochictis centennii n. g. n. sp. az egeresi felső oligocénől [Kochictis centennii n. g. n. sp., an ancient creodont from the late Oligocene of Transylvania]. - Földtani Közlöny, 73: 10-17. (in Hungarian)

Kurtén, B. (1976): Fossil Carnivora from the late Tertiary of Bled Douarah and Cherichira, Tunisia. - Notes du Service Géologique de Tunisie, 42: 177-214.

Kuss, S. E. (1962): Problematische Caniden des europäischen Tertiärs. - Berichte der Naturforschenden Gesellschaft Freiburg im Breisgau, 32: 123-172.

Kuss, S. E. (1965): Revision der europäischen Amphicyoninae (Canidae, Carnivora, Mammalia) ausschließlich der voroberstampischen Formen. - Sitzungsberichte der Heidelberger Akademie der Wissenschaften, 1965(1): 1-168.

Lartet, E. (1851): Notice sur la colline de Sansan, suivie d'une récapitulation des diverses espèces d'animaux vertébrés fossiles, trouvés soit à Sansan, soit dans d'autres gisements $\mathrm{du}$ terrain tertiaire miocène dans le bassin souspyrénéen. - J. A. Portes, Auch, 45 pp.

Mayet, L. (1908): Études de Mammifères miocènes des sables de l'Orléanais et des faluns de la Touraine. - Annales de l'Université de Lyon, Nouvelle série, 24: 1-336. https://doi.org/10.5962/bhl.title.52982

Mein, P., Ginsburg, L. (2002): Sur l'âge relatif des différents dépôts karstiques miocènes de La Grive-Saint-Alban (Isère). - Cahiers scientifiques du Muséum d'histoire naturelle de Lyon - Centre de conservation et d'étude des collections, 2002(2): 7-47.

Meyer, H. von (1849): Wirbelthier-Reste... [Letter on various fossils]. - Neues Jahrbuch für Mineralogie, Geognosie, Geologie und Petrefakten-Kunde, 1849: 547-550. 
Morales, J., Abella, J., Valenciano, A. (2017): Thaumastocyon: los extraños Amphicyonidae de Batallones 3 [Thaumastocyon: The strange Amphicyonidae from Batallones 3]. - In: Morales, J. (ed.), La colina de los Tigres Dientes de sable. Los yacimientos miocenos del Cerro de los Batallones (Torrejón de Velasco, Comunidad de Madrid) [The hill of the Saber-toothed tigers. The Miocene sites of the Cerro de los Batallones (Torrejón de Velasco, Community of Madrid)]. Museo Arqueológico Regional, Comunidad de Madrid, Alcalá de Henares, pp. 338-351. (in Spanish)

Morales, J., Pickford, M., Valenciano, A. (2016): Systematics of African Amphicyonidae, with descriptions of new material from Napak (Uganda) and Grillental (Namibia). - Journal of Iberian Geology, 42: 131-150.

Noulet, J. B. (1876): Note sur un gisement du Canis palaeolycos, dans le Miocène toulousain. - Mémoires de l'Académie des Sciences, Inscriptions et Belles-Lettres de Toulouse, 8: 400-403.

Peterson, O. A. (1907): The Miocene beds of western Nebraska and eastern Wyoming and their vertebrate faunae. - Annals of the Carnegie Museum, 4: 21-72.

Peigné, S., Heizmann, E. P. J. (2003): The Amphicyonidae (Mammalia: Carnivora) from the Early Miocene locality of Ulm-Westtangente, Baden-Württemberg, Germany: systematics and ecomorphology. - Stuttgarter Beiträge zur Naturkunde, Serie B (Geologie und Paläontologie), 343: 1-133.

Peigné, S., Salesa, M. J., Antón, M., Morales, J. (2008): A new Amphicyonine (Carnivora: Amphicyonidae) from the Upper Miocene of Batallones-1, Madrid, Spain. Palaeontology, 51: 943-965. https://doi.org/10.1111/j.1475-4983.2008.00788.x

Pomel, A. (1846): Mémoire pour servir à la géologie paléontologique des terrains tertiaires du département de l'Allier. - Bulletin de la Société géologique de France, 3: 353-373.

Schaller, O. (2007): Illustrated Veterinary Anatomical Nomenclatures, $2^{\text {nd }}$ ed. - Enke Verlag, Stuttgart, 614 pp.
Schinz, R. H. (1825): Das Thierreich, eingetheilt nach dem Bau der Thiere als Grundlage ihrer Naturgeschichte und der vergleichenden Anatomie. Vierter Band. Zoophyten. - Stuttgart, Tübingen, XIII + 793 pp.

Schlosser, M. (1901): Zur Kenntnis der Säugethierfauna der böhmischen Braunkohlenformation. - Abhandlungen des Deutschen Naturwissenschaftlich-Medicinischen Vereines für Böhmen 'Lotos', 2: 60-102.

Stehlin, H. G., Helbing, H. (1925): Catalogue des Ossements de Mammifères Tertiaires de la Collection Bourgeois. - Bulletin de la Société d'Histoire Naturelle et d'Anthropologie du Loir-et-Cher, 18: 77-277.

Suess, E. (1861): Über die großen Raubtiere der österreichischen Tertiärablagerungen. - Sitzungsberichte der kaiserlichen Akademie der Wissenschaften Mathematischnaturwissenschaftliche Klasse, Abt. 1, 43: 217-232.

Swofford, D. L. (2002): PAUP*. Phylogenetic Analysis using Parsimony (*and other methods), version 4. Sinauer Associates, Sunderland, Massachusetts.

Trouessart, E. (1885): Catalogue des mammifères vivants et fossiles. Carnivores. - Bulletin de la Société des Études Scientifiques d'Angers, supplément à l'année 1884: 1-108. https://doi.org/10.5962/bhl.title.63808

Viranta, S. (1996): European Miocene Amphicyonidae taxonomy, systematics and ecology. - Acta Zoologica Fennica, 204: 1-61.

Viret, J. (1929a): Les faunes de Mammifères de l'Oligocène supérieur de la Limagne bourbonnaise. - Annales de l'Université de Lyon, Nouvelle série 1, 47: 1-329.

Viret, J. (1929b): Tomocyon grivensis et les Canidés de la Grive-Saint-Alban. - Bulletin de la Société géologique de France, 29: 217-226.

Wang, X. M., Wang, H. J., Jiangzuo, Q. G. (2016): New record of a haplocyonine amphicyonid in early Miocene of Nei Mongol fills a long-suspected geographic hiatus. - Vertebrata PalAsiatica, 54: 21-35.

Wortman, J. L. (1901): A new American species of Amphicyon. - American Journal of Science, 11: 200-204. https://doi.org/10.2475/ajs.s4-11.63.200 


\section{Explanations to the plates}

\section{PLATE 1}

Peignecyon felinoides n. gen. et n. sp., from Tuchořice, the Czech Republic

1. Right mandible (holotype: NM-Pv 11600 right mandible with c, p1 alveolus, p4-m1, and alveoli for m2-m3); a) buccal view, b) p4-m1 in lingual view, c) occlusal view.

2. Canine of the holotype mandible; a) buccal view, b) distal view, c) lingual view, d) distal cristid in lingual view.

\section{PLATE 2}

Peignecyon felinoides n. gen. et n. sp., from Tuchořice, the Czech Republic

1. Left mandible with $\mathrm{p} 3$ alveolus, $\mathrm{p} 4-\mathrm{m} 2$, and alveolus for m3 (TU 73917); a) buccal view, b) occlusal view, c) lingual view.

2. Left mandible with p4 (TU 739137); a) buccal view, b) occlusal view, c) buccal view.

\section{PLATE 3}

Peignecyon felinoides n. gen. et n. sp., from Tuchořice, the Czech Republic

1. Right mandible with m1-m2 (TU 739118); a) buccal view, b) occlusal view, c) lingual view.

2. Left mandible with p4-m1 (TU 739115); a) buccal view, b) occlusal view, c) buccal view, d) distal view.

3. Right mandible with p4-m2 (TU 7391147); a) lingual view, b) occlusal view, c) buccal view, d) distal view.

4. Right mandible with m1-m3 (TU 739111); a) buccal view, b) occlusal view, c) lingual view.

5. Left m2 (TU 739151); a) occlusal view. 
PLATE 1
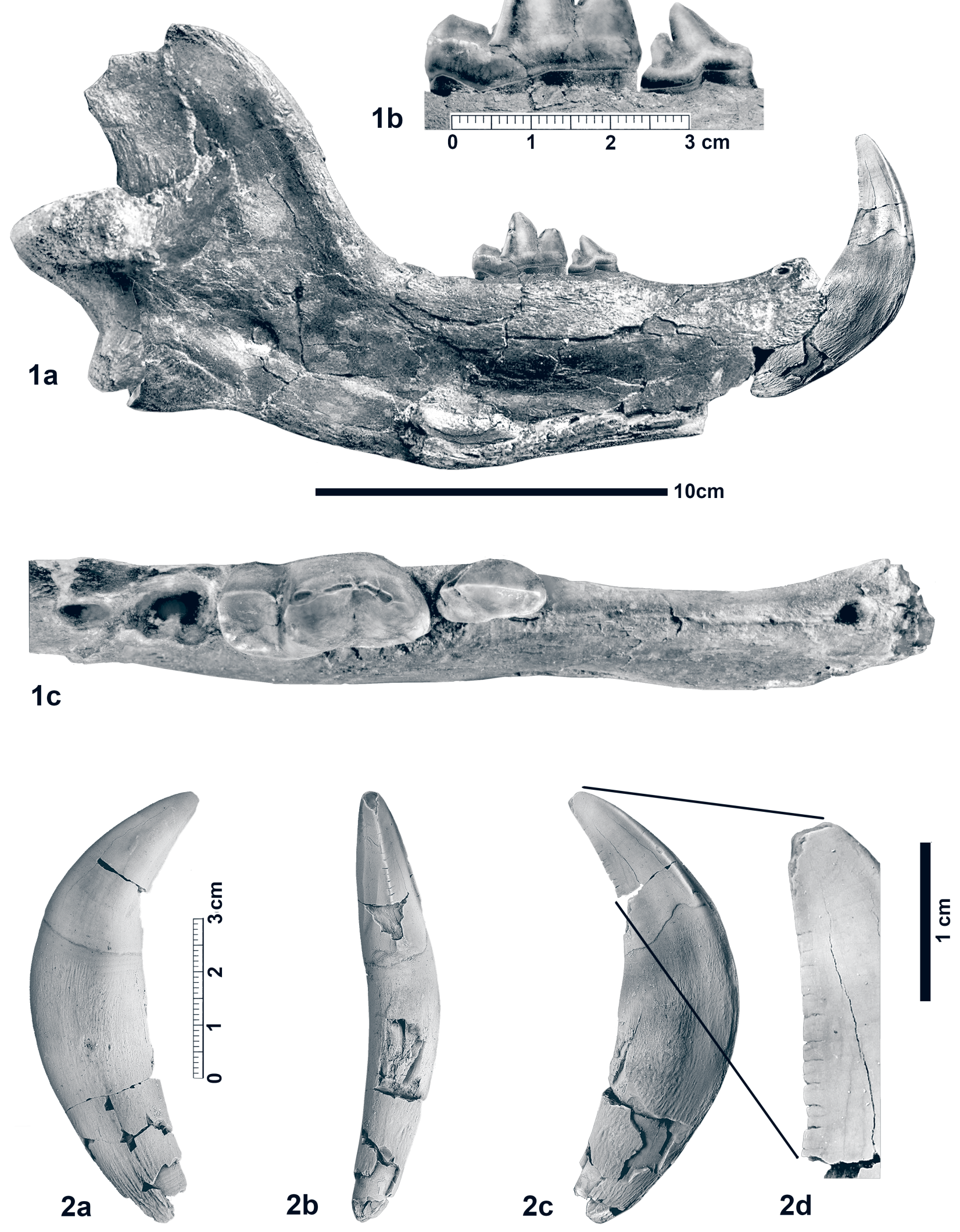
PLATE 2
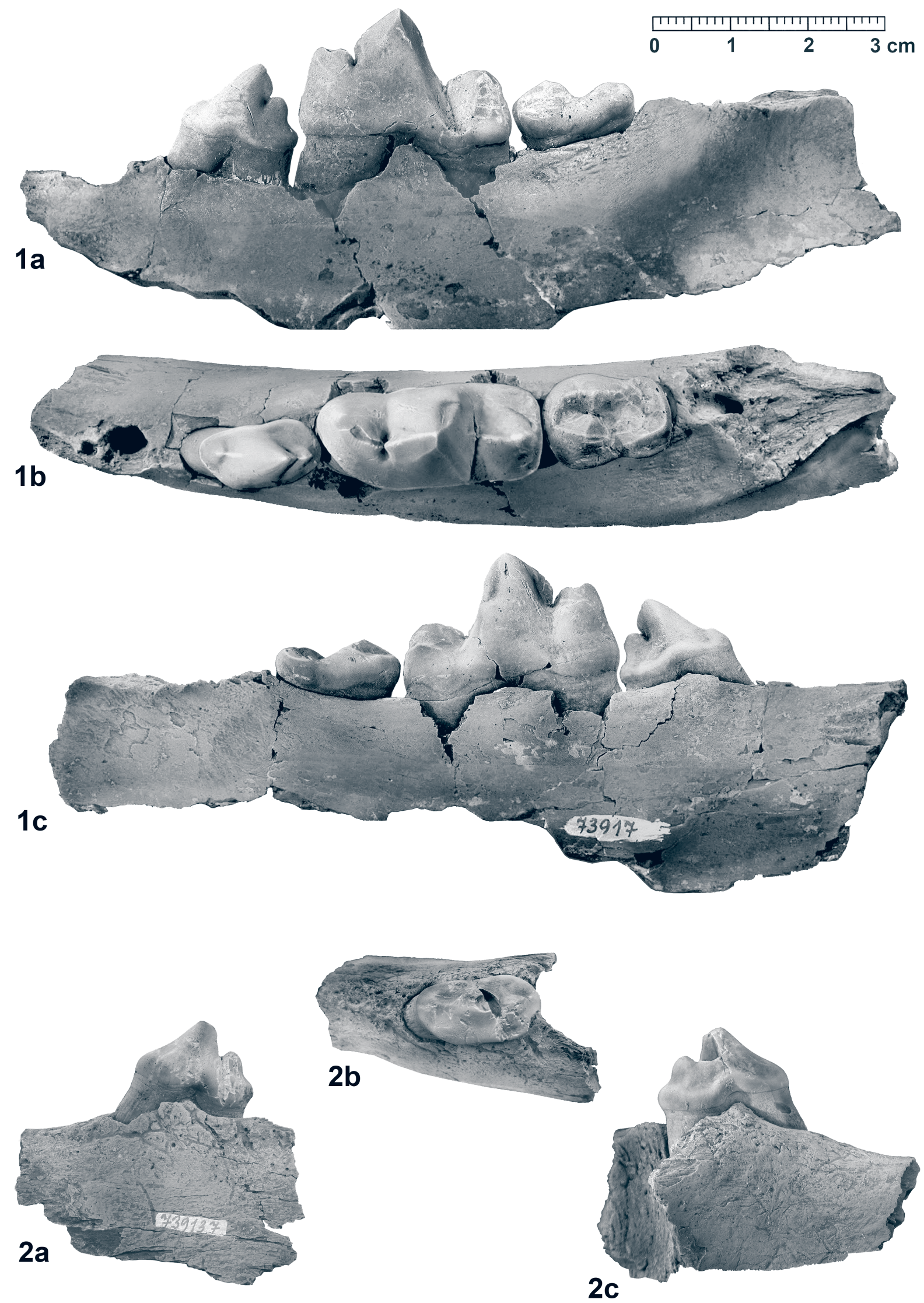
PLATE 3
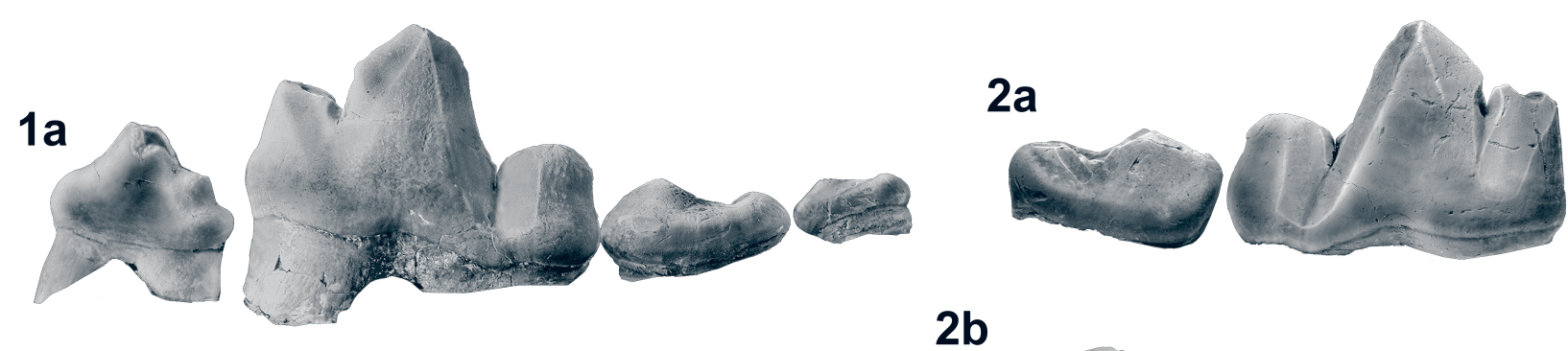

2b

$1 b$
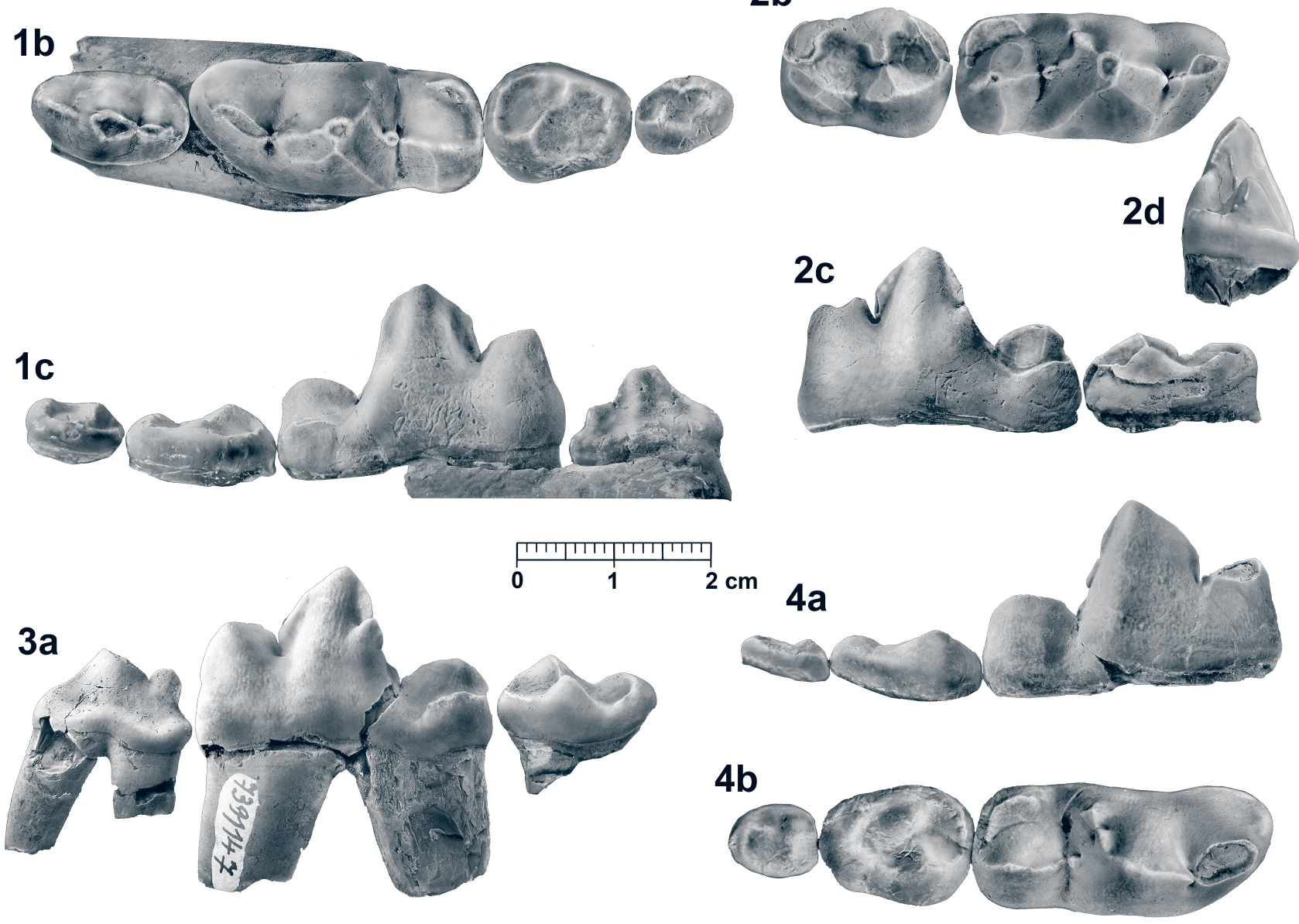

$3 b$
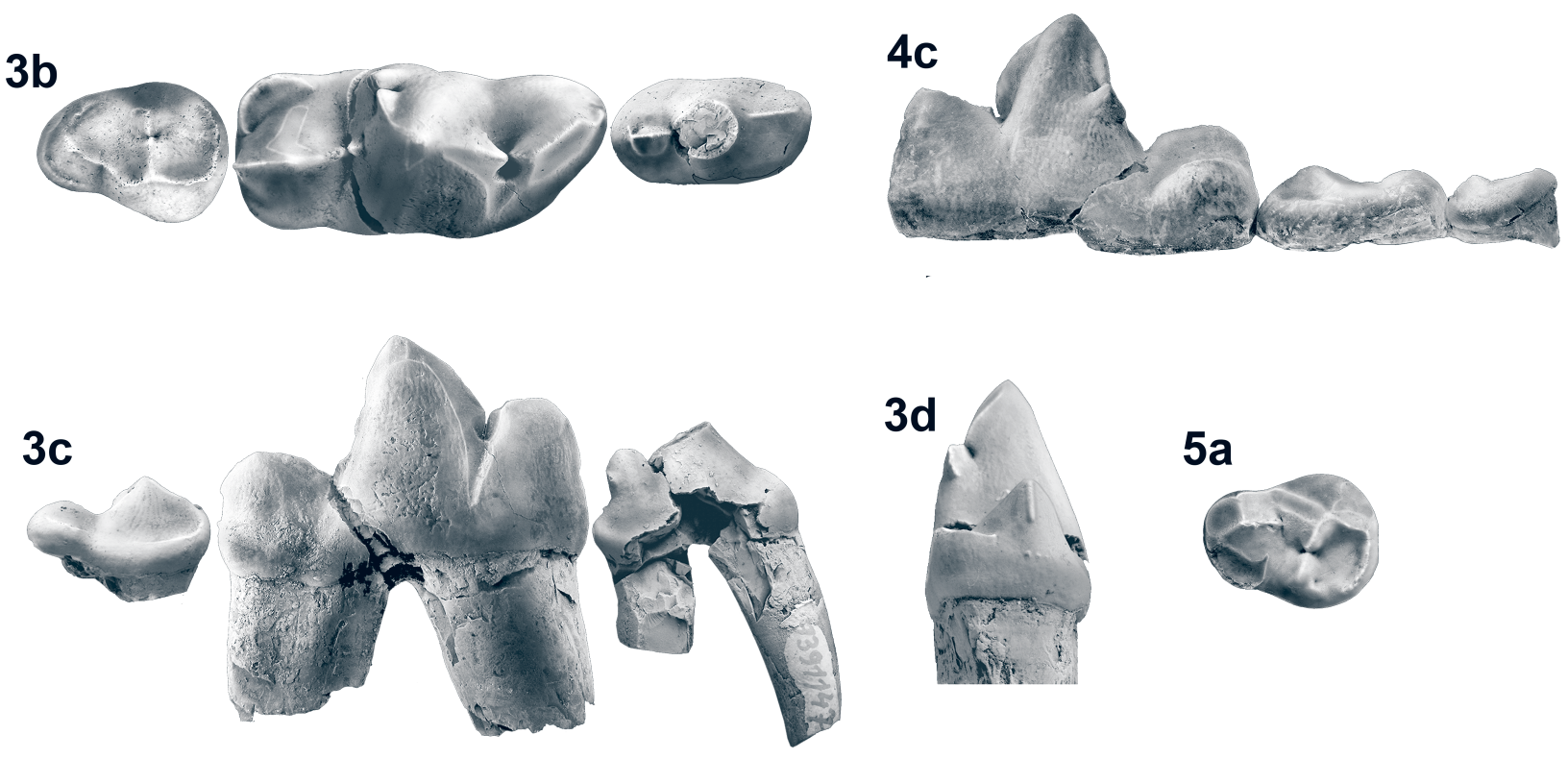